\title{
LA INMACULADA CONCEPCIÓN EN ALGUNAS ESTAMPAS DE LIBROS EDITADOS EN NUEVA ESPAÑA EN LOS SIGLOS XVIII Y XIX.
}

\author{
JUAN ISAAC CALVO PORTELA \\ Universidad Nacional Autónoma de México
}

Resumen

En este artículo abordamos el estudio de unas estampas dedicadas a la Inmaculada Concepción, que ilustran unos libros publicados en Nueva España en los siglos XVIII y XIX. El análisis de las mismas se centra en la iconografía, pero no por ello se pasa por alto los aspectos técnicos y estilísticos. Dichas estampas están reunidas en tres grupos, obedeciendo al tipo iconográfico de la Inmaculada que se plasma, en el primer grupo se incluyen aquellas con el tema de la Tota Pulchra, en el segundo las que presentan el tipo definitivo de la misma y en el último grupo incluimos dos estampas con un sentido alegórico-conceptual.

Palabras clave

Inmaculada Concepción, Nueva España, imprenta, estampa, talla dulce, entalladura.

\section{THE IMMACULATE CONCEPTION IN SOME ENGRAVINGS OF BOOKS PUBLISHED IN NEW SPAIN IN THE $18^{\mathrm{TH}}$ AND $19^{\mathrm{TH}}$ CENTURIES.}

\begin{abstract}
In this article we study of the engravings dedicated to the Immaculate Conception which illustrate books published in New Spain in the $18^{\text {th }}$ and 19 th centuries. Their analysis focuses on iconography, and technical and stylistic aspects are also taken in account. These engravings are grouped in three groups, obeying the iconographic type of the Immaculate that is reflected, in the first group they include those with the theme of the Tota Pulchra, in the second they present the definitive type of the same and in the last group we included two engravings with an allegoricalconceptual sense.
\end{abstract}

Keys words:

Immaculate Conception, New Spain, press, engraving, woodcuts.

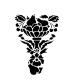

Ucoarte. Revista de Teoría e Historia del Arte, 6, 2017, pp.69-92. ISSN: 2255-1905 


\section{Introducción histórica.}

El culto y devoción a la Madre de Dios arraigó prontamente en el mundo novohispano, al mismo tiempo que tenía lugar la conquista por parte de los españoles. En ello jugaron un papel preponderante las distintas órdenes religiosas que participaron en la evangelización. Una de las primeras devociones marianas en llegar fue la de la Inmaculada Concepción que tuvo un enorme calado en la sociedad novohispana a lo largo de todo el período colonial.

La doctrina inmaculista hunde sus raíces en el mundo oriental medieval ${ }^{1}$, aunque llegó rápidamente a Occidente, asentándose en los Reinos Peninsulares medievales. La defensa de la doctrina se convirtió en un asunto de estado desde finales del siglo XVI y muy especialmente a lo largo del siglo XVII, con los Austrias Menores. Los dos primeros reyes españoles de dicha dinastía, Carlos I y Felipe II, no apoyaron directamente la doctrina inmaculista, sino que dejaron su discusión en manos de los teólogos, ya que quisieron evitar inmiscuirse en controversias teológicas que se llevaban debatiendo desde hacía siglos para centrarse en el problema de la Reforma. Es durante sus reinados cuando la doctrina comienza a enraizar en la Nueva España, al mismo tiempo que están teniendo lugar las sesiones conciliares de Trento que van a marcar profundamente la religiosidad católica de las siguientes centurias.

El Concilio tridentino no se centró en problemas mariológicos, debido a que tenía que tratar demasiadas cuestiones dogmáticas puestas en duda por los reformadores ${ }^{2}$. La doctrina inmaculista fue abordada en los debates que precedieron a la quinta sesión del 17 de junio de 1548, en la que se aprobó el Decreto sobre el Pecado Original. El Concilio optó por una fórmula que no contentó al bando inmaculista, pero que afirmaba que no era la intención del Sínodo aplicar a la Madre de Dios, lo que en el decreto se decía sobre el Pecado Original. El Concilio no condenó ninguna de las dos posturas, lo que finalmente condujo a las disputas inmaculistas que tuvieron como epicentro España, sobre todo Sevilla en las primeras décadas del siglo XVII.

Como señalábamos al comienzo, el fervor por la doctrina inmaculista caló rápidamente en el territorio novohispano, algunos han identificado la imagen de la Virgen del Estandarte de Hernán Cortés con la Inmaculada. Tanto los poderes políticos comenzando por los monarcas y los virreyes y los poderes religiosos se sirvieron de la defensa del misterio y de los resortes de la propia cultura tridentina para apuntalar la idea unitaria del Imperio ${ }^{4}$. Las órdenes religiosas jugaron un papel fundamental en la implantación del fervor inmaculista en la Nueva España, los primeros en llegar, los franciscanos fueron fervientes defensores del misterio y a ellos se les unieron los mercedarios, las concepcionistas que habiendo sido fundadas por sor Beatriz de Silva a fines del siglo XV, llegaron al Virreinato a penas un siglo después y fueron las primeras en fundar un convento femenino en Ciudad de México, y los jesuitas que fueron ardorosos valedores de la doctrina. En el año 1618 el arzobispo de México, Juan Pérez de la Serna, comunicó que el Papa había impuesto silencio al bando maculista, además se estableció que se oficiasen fiestas a la misma en el mes de diciembre. Un año después la Universidad Pontificia de México celebró unas importantes fiestas en honor de la Purísima, en las que participaron todos los gremios de la ciudad; además se fijó en sus estatutos que para obtener cualquier grado había que hacer voto de defensa a la Purísima Concepción ${ }^{5}$.

En el año 1661 el papa Alejandro VII cedió a las presiones ejercidas por Felipe IV, y por medio de la bula Sollicitudo omnium ecclesiarum, se proclamó solemnemente el misterio, aunque no se reconocía como dogma de fe. En 1664 el pontífice despachó un breve, ordenando al clero

\footnotetext{
1 Tormo, 1915: 13. Trens, 1946: 165. Stratton-Pruitt, 1988: 3. Cabello Morales, 2004: 294.

2 Sebastián, 1981: 195

3 Vargaslugo, 2004: 69-70. Martínez, 2004: 126.

${ }^{4}$ Doménech García, 2014: 54

5 Vargaslugo, 2004: 71-72.
} 
regular y secular de España e Indias rezar el oficio y decir Misa a la Inmaculada ${ }^{6}$. Este mismo pontífice años más tarde, nuevamente por presiones del rey español, Carlos II, en el breve In Excelsa, estableció como obligatorio el oficio de la Inmaculada con octava en toda la Iglesia ${ }^{7}$. El cambio dinástico a raíz de la muerte de Carlos II sin descendencia, no supuso un enfriamiento del fervor inmaculista de la Corona. Felipe $\mathrm{V}$ se va a mostrar un ardoroso defensor de la doctrina, como prueba el hecho de que en 1732 envió una carta personal, acompañada de otras doscientas súplicas de prelados de sus dominios, al papa Clemente XII a favor de la definición dogmática. Anteriormente, en 1708, el papa Clemente XI por medio de la bula Commissi nobis, extendió a toda la Iglesia la fiesta de la Inmaculada. En el año 1760 el papa Clemente XIII, nombraba a la Inmaculada patrona de España y sus dominios, siendo confirmado un año después por Carlos $\mathrm{III}^{8}$, lo que tuvo su reflejo a ambos lados del océano, tanto en los libros como en las representaciones artísticas, podemos poner como ejemplos, la Oración panegírica de María Santísima en su Concepción Inmaculada, Patrona de España y de sus Indias, de fray Pedro de Oronzoro, editado en México, en 1762, o el lienzo anónimo de la antigua casa Profesa de Ciudad de México, Patrocinio de la Virgen sobre las autoridades civiles, eclesiásticas y jesuitas. En 1767, se despacharon varios breves papales, a instancias del monarca español para que se rezasen todos los sábados no impedidos el oficio y misa de la Purísima Concepción y para que se incorporase en las Letanías de la Virgen, tras el versículo Mater Intemerata la salutación Mater Inmaculata. Esta nueva letanía la vamos a encontrar en una de las estampas que vamos a estudiar.

\section{La Iconografía Inmaculista en las estampas novohispanas del siglo XVIII.}

En este artículo vamos analizar una serie de estampas con motivos inmaculistas que ilustran libros impresos en Nueva España a lo largo del siglo XVIII y en las primeras décadas de la siguiente centuria. Todos ellos, salvo uno, salieron de algunas de las imprentas establecidas en Ciudad de México. Estos grabados fueron abiertos tanto por medio de la entalladura como por la talla dulce, demostrando como la introducción de este último procedimiento por el flamenco, Samuel Stradanus, activo en la capital virreinal en el primer tercio del siglo XVII, no supuso la desaparición de la entalladura. En el empleo de estos procedimientos podemos atisbar una diferencia en la concepción del propio artista, puesto que ninguna de las entalladuras están firmadas, mientras que todas las estampas realizadas sobre plancha de cobre tienen las firmas de los grabadores, entre los que se incluyen algunos de los más destacados de toda la centuria. Por desgracia el estudio del arte gráfico virreinal de estas centurias ha pasado hasta la fecha muy desapercibido, salvo por las aportaciones de Kelly Donahue-Wallace. En la mayor parte de los estudios se ha insistido en la influencia del grabado europeo sobre la pintura y la escultura virreinal, pero no sobre las estampas creadas por artistas novohispanos.

Estas estampas vamos a agruparlas en tres grupos, dependiendo del tipo iconográfico que se emplee para plasmar el misterio. El primer grupo está formado por aquellas obras en las que se sigue el tipo de la Tota Pulchra, el segundo por las que presentan la imagen definitiva de la Inmaculada y el tercer grupo está formado por dos estampas con un fuerte sentido alegóricoconceptual.

La Tota Pulchra no sólo fue la primera, sino la única representación del misterio inmaculista en Nueva España desde los albores de la evangelización hasta bien avanzada la siguiente centuria, aunque con variantes, que funden arcaísmo y modernidad ${ }^{10}$, pueden servirnos de ejemplo las

\footnotetext{
${ }^{6}$ Fernández Gracia, 2004: 32.

7 VV.AA., 1979, Vol. IV: 460.

8 Martínez Puche, 2005: 132.

${ }^{9}$ Fernández Gracia, 2004: 34.

10 Doménech García, 2015: 282.
} 


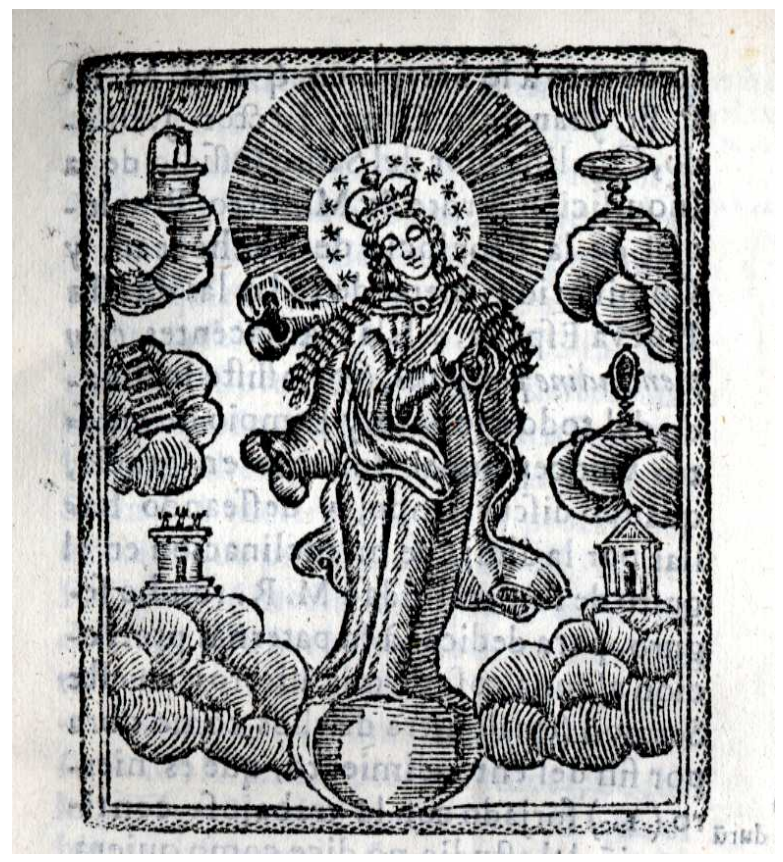

Fig. 1. Anónima, "Tota Pulchra", en Baltasar de la Carrera, Sermón predicado en la solemne acción de gracias, que por los triumphos que la magestad de $N^{o}$ Catbolico Rey y $S^{r}$ de las Españas Philipe $V$ contra sus enemigos tiene alcançados, (Imprenta de la Viuda de Miguel de Ribera, México, 1712). Entalladura. Biblioteca Palafoxiana, $\mathrm{N}^{\mathrm{o}}$ de localización 15554. $\quad(103 \times 81$ $\mathrm{mm}$.).

pinturas murales de los cenobios franciscanos de Huejotzingo y Cholula. Este tipo iconográfico tuvo su origen a comienzos del siglo XVI en una estampa francesa ${ }^{11} \mathrm{y}$ fue definido por Molanus en su tratado ${ }^{12}$. Esta tipología bebe de dos fuentes medievales, una literaria que son las llamadas Mariologías que hacen referencia a la virginidad de María y no estrictamente a su Concepción Inmaculada, siendo san Bernardo el primero en establecerlas y a lo largo de la Baja Edad Media se fueron envolviendo de una mayor poesía, dando lugar a las Letanías, y otra fuente gráfica que son las Äbrenkleidjungfrau, que son unas sencillas entalladuras en las que se representa a la Virgen muy joven antes de su desposorio con san José ${ }^{13}$.

En todas las estampas en las que se representa a la Tota Pulchra, la figura de la Virgen responde a los perfiles de la Mulier amicta sole, tomada del libro del Apocalipsis, que hunde sus raíces en la Edad Media. Sin embargo, esta imagen no fue exclusiva de la Inmaculada, sino que se usó para captar otras imágenes marianas como la Reina de los Cielos o de los Ángeles, la Asunción, la Virgen de la Humildad o la Virgen del Rosario ${ }^{14}$. Al mismo tiempo, se produce la identificación de la Tota con la Nueva Eva anunciada por Dios en el Génesis. En ninguna de estas estampas encontramos la inscripción del Cantar de los Cantares: "Tota Pulchra es, amica mea, et macula non est in te" $(\mathrm{Ct}, 4,7)$, que definiría este tipo iconográfico ${ }^{15}$. Tampoco hallamos la figura de Dios Padre, bendiciendo o coronando a la Virgen, que haría referencia a la creación de María en la mente de Dios antes del tiempo o al triunfo de la Virgen tras su elevación a los Cielos.

La primera de estas estampas es una entalladura que ilustra el Sermón predicado en la solemne acción de gracias, que por los triumphos que la magestad de $N^{o}$ Catholico Rey y $S^{r}$ de las Españas Philipe $V$

\footnotetext{
11 Stratton-Pruitt, 1988: 35.

12 García Mahíques, 1996-1997: 177-178. Doménech García, 2015: 278.

13 Stratton-Pruitt, 1988: 35.

14 García Mahíques, 1995: 190. Doménech García, 2015: 301.

15 Doménech García, 2015: 279.
} 
Fig. 2. Anónima, "Tota Pulchra", en José Díez, Aljaba apostólica de penetrantes flechas, para rendir la fortaleza del duro Pecador, en varias Canciones y Saetas, que acostumbran a cantar en sus Misiones los RR.PP. Misioneros Apostólicos de N.S.P. San Francisco, (Imprenta de la Viuda de Miguel de Ribera, México, 1731). Entalladura. Biblioteca Nacional de México, RSM 1731 M4DIE. $(84 \times 53 \mathrm{~mm})$.

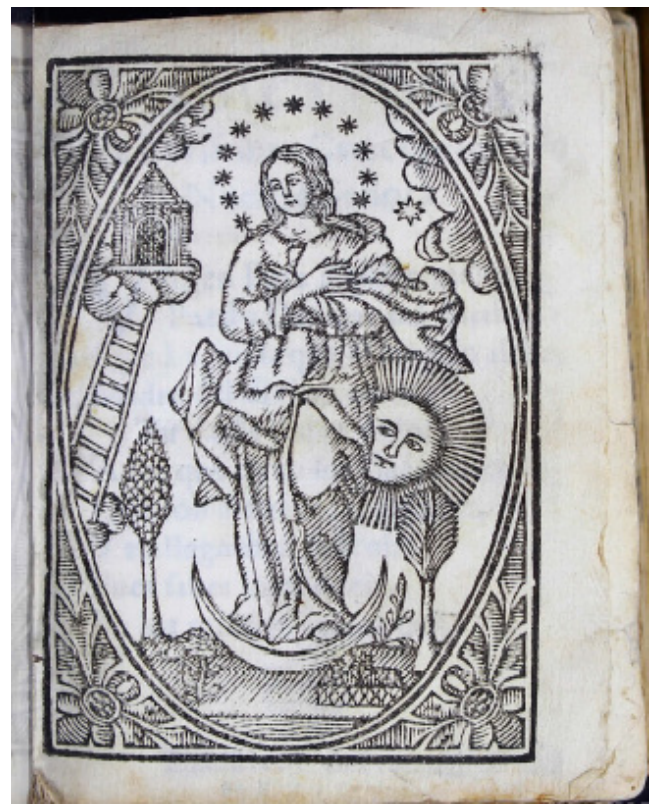

contra sus enemigos tiene alcançados, de fray Baltazar de la Carrera, publicado por la viuda de Miguel de Ribera en $1712^{16}$, aunque el sermón fue predicado el 6 de agosto de 1711, en el convento franciscano de la Asunción en Toluca. Este tipo de sermones dedicados a la Inmaculada Concepción fueron habituales tanto en la Península como en Nueva España, a lo largo del siglo XVII, puede servirnos de ejemplo el Sermón de la Inmaculada Concepción de María Señora Nuestra, predicado en el celebre, y devotissimo Santuario de la Soledad y Dolores de la misma SS. Virgen en la Ciudad de Guadalaxara año de 1693, del jesuita Miguel de Castilla ${ }^{17}$. Estos impresos de escasa entidad constituyeron una de las principales fuentes de ingresos de las imprentas tanto españolas como novohispanas, a lo largo de estos siglos.

La Virgen está en el centro de un espacio indefinido, quizás para aludir a su creación antes del tiempo, con la luna creciente bajo sus pies, uniendo sus manos a la altura del pecho en oración e inclina la cabeza hacia su hombro derecho (Fig. 1). Va vestida con un manto cuyos pliegues parece agitar el viento y con una túnica, sobre su cabeza tiene la corona imperial y a su alrededor un nimbo de doce estrellas. La presencia de la corona imperial no va a ser extraña en las representaciones novohispanas de la Inmaculada, tanto en pinturas como la atribuida a Manuel de Echave Orio, como en estampas. Esta inclusión se basa en las recomendaciones de Francisco Pacheco en su tratado y que acreditaba su origen revelado a sor Beatriz de Silva, fundadora de la orden concepcionista, y por ende, a su vínculo con el proyecto mesiánico del príncipe católico ${ }^{18}$.

Uno de los elementos que van a definir el tipo de la Tota Pulchra es la presencia de los emblemas marianos, tomados de las Letanías marianas medievales, cuyo padre fue san Bernardo $^{19}$. Éstas tenían su fuente en el Antiguo Testamento, principalmente en los libros del Cantar de los Cantares, la Sabiduría y el Eclesiástico, y no fueron exclusivos de la Inmaculada, sino que hacían hincapié en la virginidad de María, siendo vinculados al misterio a partir del siglo

\footnotetext{
16 Biblioteca Palafoxiana, $\mathrm{N}^{\mathrm{o}}$ de localización 15554, libro primero. $81 \times 103 \mathrm{~mm}$.

17 Biblioteca Nacional de México (desde ahora BNM), RSM 1694 M4CAS JJGC.

18 Cuadriello, 2009: 1200.

19 Doménech García, 2015: 280-282.
} 


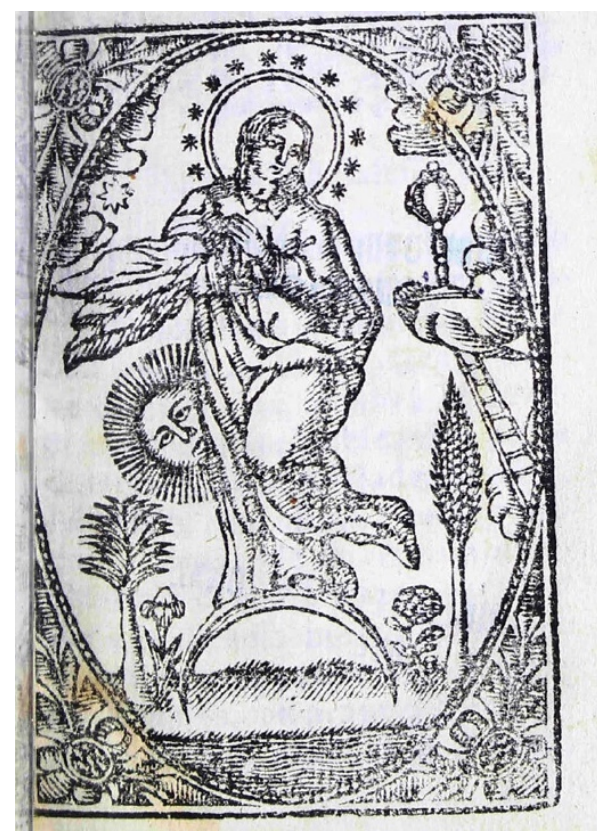

Fig. 3. Anónima, "Tota Pulchra", en Día ocho del mes, en que baciendo dulce recuerdo de la Purissima Concepción de María Santissima, (José Jáuregui, México, 1775). Entalladura. Biblioteca Nacional de México, RSM 1775 M4DIA. (85×55 mm).

$\mathrm{XVI}^{20}$. En esta estampa, a los lados de la Virgen hay unas bandas de nubes sobre las que se disponen algunos de ellos, a la izquierda de abajo arriba vemos, la torre de marfil, la escalera de Jacob y el pozo, y a la derecha se encuentran el templo de Dios, el espejo sin mancha y la fuente.

La siguiente estampa se dispone en el folio que sigue a la portada tipográfica de la edición de 1731 de la obra de José Díez, Aljaba apostólica de penetrantes flechas, para rendir la fortaleza del duro Pecador, en varias Canciones y Saetas, que acostumbran a cantar en sus Misiones los RR.PP. Misioneros Apostólicos de N.S.P. San Francisco (Fig. 2) ${ }^{21}$. La elección del motivo no resulta fortuita, puesto que el libro está dedicado a la Inmaculada Concepción, como se desprende de los versos de la Dedicatoria. Además en el mismo se incluye unos "Gozos a la Purísima Concepción de Nuestra Señora"22, que comienzan de esta manera:

«Para dar luz inmortal,

Siendo voz Alva del día,

Sois concebida, MARIA,

Sin pecado original» ${ }^{23}$.

Se trata de una entalladura que carece de las firmas del inventor, grabador y editor. Tiene un formato rectangular que enmarca un óvalo, apareciendo en las enjutas unas flores muy esquemáticas. A diferencia de la anterior, en esta la Virgen no se dispone en un espacio indefinido, sino que la escena tiene lugar entre el Cielo y la tierra. La figura responde al modelo derivado de la Mujer del Apocalipsis, con la creciente bajo sus pies y las doce estrellas sobre su cabeza, cruzando sus brazos sobre su pecho en actitud de recogimiento. Es una figura de gran belleza, vestida con unas telas que se agitan en el aire por el viento. A su alrededor se encuentran

\footnotetext{
20 Doménech García, 2015: 301.

21 BNM, Fondo Reservado, RSM 1731 M4DIE.

22 Díez, 1731: 400-404.

${ }^{23}$ Díez, 1731: 400.
} 
Fig. 4. Anónima, "Tota Pulchra", en José Díez, Aljaba apostólica de penetrantes flechas, para rendir la fortaleza del duro Pecador, en varias Canciones y Saetas, que acostumbran a cantar en sus Misiones los RR.PP. Misioneros Apostólicos de N.S.P. San Francisco, (s.n., México, 1785). Entalladura. Biblioteca Nacional de México, RSM 1785 M4DIE. $(85 \times 61 \mathrm{~mm})$.

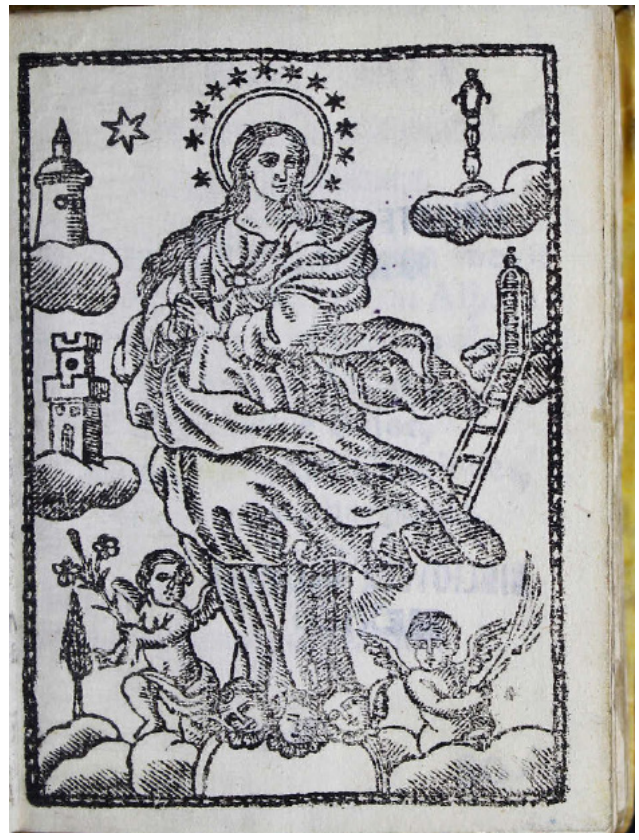

algunos de los símbolos de las letanías, distribuidos entre el Cielo y la tierra. En la parte terrenal encontramos, en el lado izquierdo el ciprés de Sión y una flor que podríamos identificar como la rosa sin espinas, a la que alude el Eclesiástico; mientras que en el lado derecho, vemos el Hortus Conclusus con unas flores, tomado del Cantar de los Cantares. En el lado derecho, bajo la luna, surge una planta que podría ser la vara de los lirios, que también se inspira en el Cantar de los Cantares, y a su lado, se encuentra la palmera, uno de los emblemas marianos más comunes. En el Cielo sobre una banda de nubes muy esquemáticas, en el lado izquierdo, atisbamos la Escala de Jacob que se menciona en el Génesis que conduce a una construcción dispuesta sobre unas nubes, quizás la Puerta del Cielo. Tras la figura de la Virgen, en el lado derecho, surge el sol con rasgos antropomórficos, aludiendo a la Electa ut Sol del Cantar de los Cantares y al mismo tiempo al vestido de sol de la Mulier amicta sole. En la parte superior derecha está la Estrella de los Mares que fue uno de los símbolos marianos más frecuentes que acompañaron a la Tota y deriva de un himno medieval.

La estampa que ilustra el libro, Día ocho del mes, en que haciendo dulce recuerdo de la Purissima Concepción de María Santíssima, editado por José Jáuregui en 1775, tiene cierto parecido con la acabamos de mencionar (Fig. 3) ${ }^{24}$, sin embargo hallamos algunas diferencias tanto en la figura de María como en los atributos que la acompañan. La figura de la Virgen no cruza sus brazos sobre su pecho, sino que une sus manos en actitud orante. Por otro lado, alrededor de su cabeza tiene un nimbo circular y sobre éste las estrellas de la mujer apocalíptica. A sus pies vemos la luna con las puntas hacia abajo, mientras que en la anterior estaban hacia arriba. También encontramos algunas sutiles diferencias en los emblemas que la acompañan, aunque se siguen distribuyendo entre el Cielo y la tierra. En la parte terrenal se ha suprimido el Hortus Conclusus con las flores que veíamos en la entalladura del libro de José Díez. En el lado izquierdo se distinguen la palmera y junto a ella brota del suelo la vara de lirios. Como en la anterior, tras la figura de la Inmaculada

${ }^{24}$ BNM, Fondo Reservado, RSM 1775 M4DIA. 85×55 mm. 


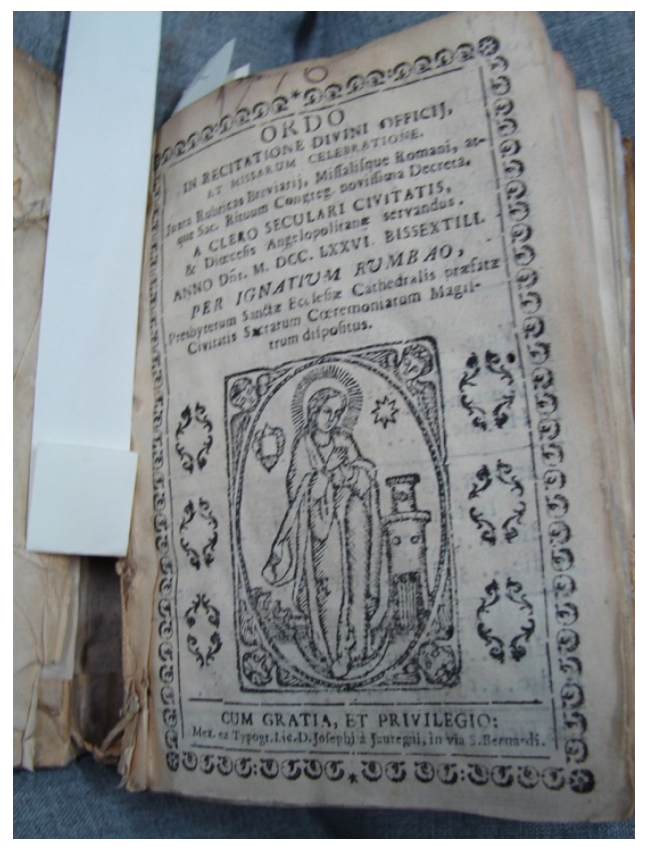

Fig. 5. Anónima, "Tota Pulchra", en Ignacio Rumbao, Ordo in recitatione divini officii et missarum celebratione, (José Jáuregui, México, 1776). Entalladura. Biblioteca Nacional de México, RSM 1776 M4IGL.

surge el sol con rasgos antropomórficos. En la parte superior izquierda, entre unas bandas de nubes muy esquemáticas, encontramos la Estrella de los Mares. A la derecha en la parte terrenal vemos el ciprés de Sión y a su lado nace una flor, posiblemente la rosa sin espinas. En el cielo sobre las nubes en el lado derecho atisbamos la escala de Jacob que no conduce a la Puerta del Cielo como en la del anterior libro, sino que sobre las nubes de la parte superior está el Espejo sin mancha que fue uno de los jeroglíficos marianos más comunes, que no sólo simbolizaba la virginidad mariana antes, durante y después del parto, sino que se extendía a su creación en la mente divina antes del tiempo ${ }^{25}$. Por otro lado, partiendo del versículo del libro de la Sabiduría (Sb. 7,26$)$ se va a incidir en la idea de la Virgen como espejo en el que se refleja el rostro de Dios, pues según el Pentateuco ningún hombre podía ver el rostro de Dios y seguir con vida. Luego la Virgen María se convierte en la mediadora entre Dios y los hombres. Esta imagen plena de poesía fue muy atractiva para los místicos, uno de los ejemplos más conocidos es el de sor María Jesús de Agreda, que de sobra es sabido la enorme influencia que ejerció su obra Mística Ciudad de Dios, en el Nuevo Mundo. En el capítulo 18, del libro primero, de la primera parte, leemos:

« (...) y toda ella semejante a un cristal purísimo, y sin un lunar, ni átomo de culpa; antes en la claridad, y pureza despide rayos, y hace visos de Divinidad, como el cristal, que herido del Sol, parece le tiene dentro de sí mismo y le retrata, reverberando como el mismo Sol» ${ }^{26}$.

En la edición del año 1785 del libro de José Díez, Aljaba apostólica de penetrantes flechas, para rendir la fortaleza del duro Pecador, en varias Canciones y Saetas, que acostumbran a cantar en sus Misiones los RR.PP. Misioneros Apostólicos de N.S.P. San Francisco ${ }^{27}$, hay una entalladura en la que se representa a la Tota Pulchra, que precede a un poema a modo de dedicatoria a la propia Inmaculada (Fig. 4). En el centro de la composición se encuentra la Virgen sobre unas cabecitas de querubines que harían las veces de peana, bajo las que observamos la creciente con las puntas hacía abajo. Gira su cuerpo hacia la izquierda, pero vuelve su cabeza a la derecha, generando una fuerte torsión

\footnotetext{
25 Rivera, 2006: 64.

${ }^{26}$ María Jesús de Agreda, 1720: 140.

${ }^{27}$ BNM, Fondo Reservado, RSM 1785 M4DIE, $61 \times 85$ mm.
} 
en todo su cuerpo. Al tiempo que une sus manos a la altura del pecho en actitud orante, que como ya hemos señalado se toma de la Mulier amicta sole. Va vestida con una túnica y una capa que se engancha con un prendedor en su pecho que cae en unos voluminosos plegados que el viento agita, potenciando la sensación de movimiento de la figura. La Virgen tiene unos largos y ondulados cabellos que le caen sobre los hombros, y alrededor de su cabeza tiene el característico nimbo con las estrellas.

En la parte inferior, junto a la luna creciente, hay unas bandas de nubes sobre las que vemos unos ángeles sosteniendo algunos de los emblemas marianos. La presencia de ángeles portando algunos de los símbolos de las letanías no va a ser extraña en las representaciones de este tipo tanto en Europa como en Nueva España, pueden servirnos de ejemplo la Benedicta del Museo Nacional del Virreinato, procedente del convento agustino de Yuriria ${ }^{28}$, o la Virgen de la Sirena de Baltasar de Echave Ibía ${ }^{29}$. El querubín de la izquierda está genuflexo hacia la izquierda, pero gira su cabeza hacia la derecha generando mucho movimiento en su cuerpo, con una de sus manitas sostiene la vara de lirios; mientras que su compañero está medio tapado por las nubes, portando la rama de palma tomada del libro Eclesiástico. Junto al querubín del lado izquierdo vemos el Ciprés de Sión que ya hemos podido apreciar en otras de las entalladuras. En este mismo lado, de abajo arriba, sobre unas bandas de nubes vemos la Torre de marfil, el Templo del Espíritu Santo y la Estrella de los mares. En el lado contrario se disponen la Escala de Jacob que conduce hasta la Puerta del Cielo, y en la parte superior está el Espejo sin mancha.

Desde el punto de vista técnico es la entalladura de mayor calidad que hemos visto hasta ahora. Aunque no está firmada, consideramos que se debe a un artista que dominaba perfectamente la técnica y no a un mero artesano. Los contornos de las figuras, las telas y las nubes se hicieron por medio de unos gruesos trazos; mientras que para generar la sensación de volumen de las telas de la Virgen, empleó unos surcos paralelos para las zonas en sombra y el blanco del papel para las partes iluminadas. La fecha tardía en la que se abrió esta estampa, un año después del establecimiento de la Real Academia de San Carlos en Ciudad de México, demuestra la pervivencia del grabado en madera durante toda la centuria, coincidiendo con el siglo de oro del grabado en cobre en Nueva España.

En algunos casos se simplificó enormemente esta figura de la Tota Pulchra, sírvanos de ejemplo la entalladura que ilustra la portada del libro del sacerdote Ignacio Rumbao, Ordo in recitatione divini officii et missarum celebratione, Juxta Rubricas Brevarii, Missalis que Romani, atque Sacrae Rituum Congregationis Novissima Decreta, impreso por el tipógrafo mexicano José Jáuregui (Fig. 5) ${ }^{30}$. Como se indica a continuación del título, este libro litúrgico está destinado al uso de la catedral de Puebla que estaba bajo la advocación de la Inmaculada Concepción, y en la que el autor ejercía como maestro de coro. Este grabado tiene un formato rectangular en el que se inserta un óvalo, en las enjutas se disponen unas cabecitas aladas de querubines. A la Virgen se la sigue representando bajo los perfiles de la Mujer Apocalíptica, aunque se han suprimido algunos de los elementos que la identificaban como las doce estrellas sobre su cabeza, conservándose exclusivamente la luna creciente bajo sus pies con las puntas hacia arriba. Sólo le acompañan algunos de los emblemas de las Letanías, en la parte inferior se encuentran a izquierda y derecha respectivamente, la Escala de Jacob y la Torre de Marfil, y a la altura de sus hombros se disponen, a la izquierda, un emblema que quizás sea el Espejo sin mancha, aunque es muy difícil de identificar, y a la derecha, la Estrella de los mares.

\footnotetext{
${ }_{28}$ Museo Nacional del Virreinato. Temple sobre tabla, $245,5 \times 184 \mathrm{~cm}$. Esta pintura Guillermo Tovar de Teresa la atribuyó a Francisco Morales. Ver Tovar de Teresa, G., Pintura y escultura del Renacimiento en México, México, INHA, 1979, pp. 174-175.

${ }^{29}$ Museo Nacional de Arte, INBA, Acervo Constitutivo, 1982.

${ }^{30}$ BNM, Fondo Reservado, RSM 1776 M4IGL.
} 
Las siguientes estampas a las que nos vamos a referir responden a la iconografía definitiva de la Inmaculada Concepción, surgida a fines del siglo XVI en España. Esta tipología acabará desplazando los motivos narrativos de origen medieval que se habían empleado para representar el misterio. Como ha señalado Doménech, la introducción del dragón-serpiente tendrá una importancia capital en la creación de este tipo iconográfico ${ }^{31}$. Su presencia permite identificarla claramente con la Nueva Eva anunciada por Dios en el Génesis: "Ipsa Conteret caput tuum" (Gn. 3,15). Estas representaciones de la Inmaculada van a ser comunes en los grabados europeos y españoles del siglo XVIII, podríamos mencionar una estampa de los hermanos Klauber, en la que la Virgen está pisando con uno de sus pies la luna y con el otro la sierpe ${ }^{32}$. En el caso español podemos citar una del grabador y pintor valenciano, Miguel Gamborino ${ }^{33}$.

Siguiendo este modelo encontramos algunas entalladuras anónimas como la que ilustra el libro del franciscano Diego de San Francisco, Exercicios de señor san Joseph, varón justo, patriarca grande, esposo purissimo de la Madre de Dios y altissimo padre estimativo de el Hijo de Dios, publicado por la Imprenta Real en 1747 (Fig. 6) ${ }^{34}$. El libro tiene otra estampa de san José con el Niño que precede a la dedicatoria al padre terrenal de Jesús. La incorporación del grabado inmaculista tenemos que ponerlo en relación con la inclusión de una "Carta de esclavitud a María Santísima. En veneración del misterio de su Purísima Concepción”, que está acompañada por unas indulgencias concedidas por el obispo de Ciudad Rodrigo, Benito Uria y Valdés.

La Inmaculada se dispone sobre una banda de nubes con unas cabecitas de querubines bajo sus pies, surgiendo de las nubes vemos las puntas de la luna creciente hacia arriba y bajo ellas está la serpiente con la fruta del Pecado Original en sus fauces que nos permite identificarla con la Nueva Eva. Bajo este pedestal hay otro poligonal como si la estampa fuese una reproducción de una estatua devocional de la Inmaculada. La Virgen une sus manos en actitud orante a la altura del pecho, sobre su cabeza tiene la corona imperial que como ya hemos visto fue un elemento frecuente en las representaciones inmaculistas novohispanas desde la anterior centuria, y el habitual nimbo de estrellas de la mujer apocalíptica. Va ataviada con una túnica y una capa con unos voluminosos plegados que se logran por medio de unos trazos gruesos en los contornos y líneas paralelas en los pliegues.

La siguiente estampa se debe a José Benito Ortuño, cuya firma apreciamos en el margen inferior, e ilustra el libro, Regla, y ordenaciones de las religiosas de la limpia, Inmaculada Concepción de la Santissima Virgen $N^{a}$ Señora, que se han de observar en los Conventos del dicho orden de la Ciudad de México: La Concepción, Regina-Coeli, Jesús María, Nra. Señora de Balbanera, la Encarnación, Santa María de Gracia y Santa Inés, que vio la luz en 1758 (Fig. 7) ${ }^{35}$. Este grabador estuvo activo en la capital virreinal en la segunda mitad del siglo XVIII, aunque no se poseen muchos datos biográficos sobre él. En algunos documentos dados a conocer por Donahue-Wallace, se indica que en 1761 se presentó al cargo de Oficial Primero para la Casa de la Moneda ${ }^{36}$ y en 1768 fue visitado como tantos otros impresores y grabadores por un clérigo de la Inquisición ${ }^{37}$.

La inclusión de esta lámina está claramente vinculada al contenido del libro, al tratarse de las reglas y constituciones de los conventos concepcionistas de la capital virreinal, entre los que se incluye el convento de la Concepción, fundado por el arzobispo fray Juan de Zumárraga, en

\footnotetext{
${ }^{31}$ Doménech García, 2015: 299.

32 Biblioteca Nacional de España (a partir de ahora BNE), Sala Goya, Colección Albert, Caja 2, H. $383 /$ C-668.

33 BNE, Sala Goya, Colección Albert, Caja 2, H. 386/C-704.

${ }_{34}$ Biblioteca Miguel Lerdo de Tejada, Fondo Reservado, 200/A1, 73×50 mm.

35 BNM, Fondo Reservado, RSM 1758 M4CONej.2, $60 \times 113 \mathrm{~mm}$.

36 Donahue-Wallance, 2000: 76-77; 2001a: 229-231.

37 Donahue-Wallace, 2000: 77; 2001b: p. 290.
} 
Fig. 6. Anónima, "Inmaculada Concepción", en Diego de San Francisco, Exercicios de señor san Joseph, varón justo, patriarca grande, esposo purissimo de la Madre de Dios y altissimo padre estimativo de el Hijo de Dios, (Imprenta Real, México, 1747). Entalladura. Biblioteca Miguel Lerdo de Tejada, Fondo reservado, 200/A1. $(73 \times 50 \mathrm{~mm})$.

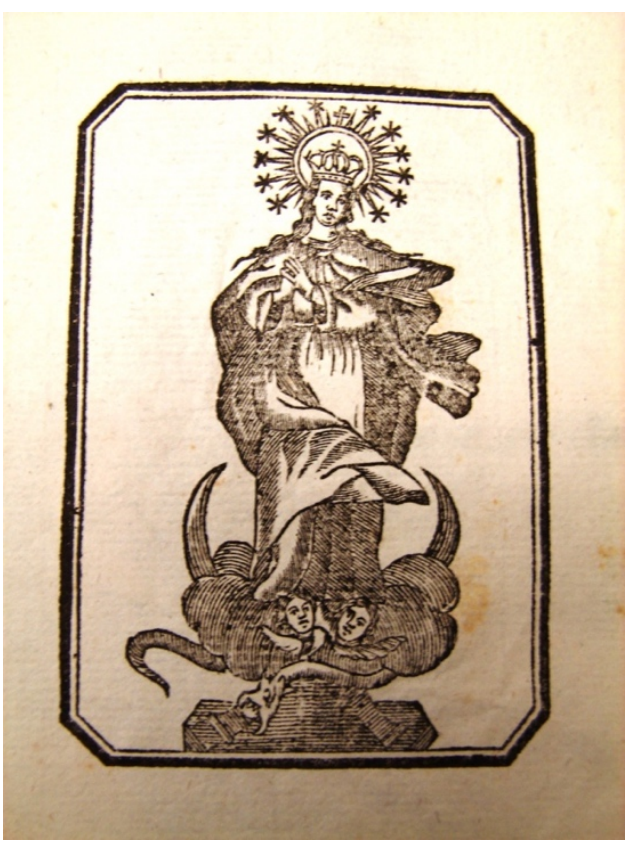

1540, que se tenía como el primer y más antiguo convento fundado en Nueva España, dando a la Orden Concepcionista un lugar muy relevante en la historia de las instituciones relgiosas en América ${ }^{38}$.

En esta estampa la Inmaculada se presenta dentro de un medallón con una rica decoración muy en la línea del gusto barroco imperante en Nueva España a mediados de la centuria. En la parte inferior, integrándose en la propia decoración, hay una cartela con el título, Mater Purissima. La Virgen se dispone sobre la luna con las puntas hacia arriba y bajo sus pies está la sierpe. Va ataviada con una túnica y un manto con unos pliegues que el viento parece agitar. La figura está envuelta en resplandores como alusión al vestido de sol de la Mujer Apocalíptica. En el espacio indefinido en el que se encuentra podemos ver algunas cabecitas aladas de querubines.

A diferencia de las obras que hemos visto hasta ahora, ésta se obtuvo a partir de una plancha de cobre, abierta por medio de los buriles y del aguafuerte, como hacían los grabadores europeos $^{39}$. José Benito Ortuño demuestra una gran habilidad técnica, combinando unos largos trazos paralelos en los resplandores que envuelven a la Inmaculada, con una tupida red de rombos en los pliegues de las telas, el blanco del papel en las partes iluminados y un suave punteado en los rostros de las figuras. Como señala Donahue-Wallace, este artista trabajó en un estilo y técnica que reflejan la estética del último barroco mexicano en pintura y grabado ${ }^{40}$.

El tipo iconográfico definitivo de la Inmaculada se siguió empleando durante el siglo XIX, como lo demuestran las siguientes estampas a las que nos vamos a referir. La primera de ellas es la única que no fue abierta en México, sino que lo fue en Guadalajara, por entonces capital del

\footnotetext{
38 Reta, 2005: p. 204.

${ }^{39}$ Donahue-Wallace, 2000: 78.

${ }^{40}$ Donahue-Wallace, 2000: 78.
} 


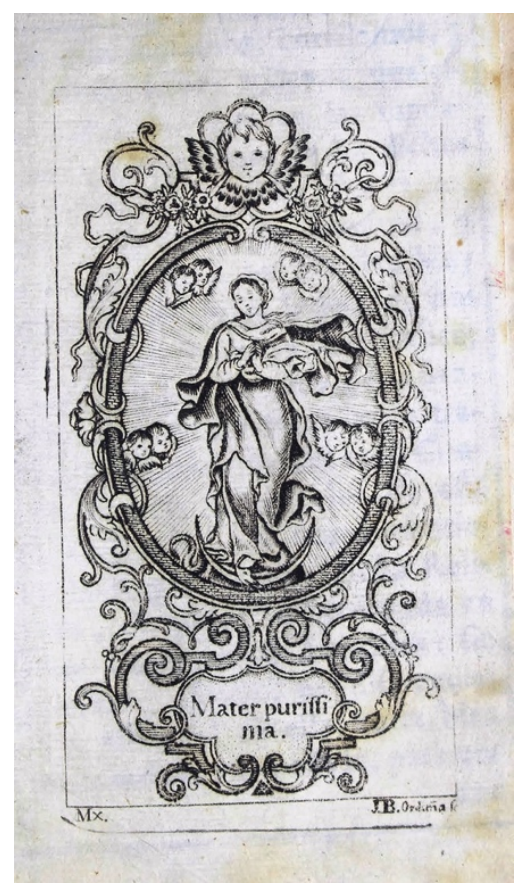

Fig. 7. José Benito Ortuño, "Inmaculada Concepción”, en Regla, ordenaciones de las religiosas de la limpia, Inmaculada Concepción de la Santissima Virgen $N^{a}$ Señora, (Herederos de María de Rivera, México, 1758). Talla dulce. Biblioteca Nacional de México, RSM 1758 M4CONej2. $(113 \times 60 \mathrm{~mm})$

Reino de Nueva Galicia. Ilustra el Sermón de la Purísima Concepción predicado el 8 de diciembre de $1804^{41}$, de fray José Ignacio María de Nava, publicado en 1806 por Mariano Valdés Téllez Girón, a quien se debe el asentamiento de la imprenta en Guadalajara en la última década del siglo XVIII ${ }^{42}$. Este sermón fue predicado en el convento de la Pursísima Concepción de Zacatecas, a devoción de los mineros de Rondanera como se indica en la portada tipográfica. En la misma se señala que tuvo lugar el 8 de diciembre, día de la fiesta de la Inmaculada, establecida por la bula Sollicitudo omnium ecclesiarum, de 1661, para España y sus territorios, y que se había extendido a toda la Iglesia por el breve In Excelsa, de 1696. Como ya hemos señalado anteriormente, la impresión de los sermones en general, y en particular de los dedicados a la Inmaculada, venía siendo habitual en el Virreinato desde el siglo XVII y constituían una de las principales fuentes de ingresos para los talleres tipográficos.

En el margen inferior hallamos la firma del grabador: "Rea s.- Guadal", que identificamos con José Simón de Larrea (Fig. 8). Los datos biográficos que tenemos sobre este grabador son sumamente escasos, posiblemente estuvo activo entre la última década del siglo XVIII y las dos primeras del XIX. Se desconoce con quien pudo formarse y se le incluye entre los grabadores independientes, es decir aquellos que ejercieron su oficio al margen de la Real Academia de san Carlos $^{43}$. Iguiniz basándose en un aviso publicado en la Gaz̧eta de México el 10 de Julio de $1795^{44}$, considera que Valdés Telléz Girón le contrató para su taller, trasladándose a Guadalajara ${ }^{45}$. No se sabe cuánto tiempo permaneció en la capital de Nueva Galicia, pero Romero Terreros

${ }^{41}$ BNM, Fondo Reservado, RSM 1806 G6NAV.

${ }^{42}$ Iguiniz, 1943: 9.

43 Donahue-Wallace, 2000: 116.

44 Gazeta México, $10 \quad$ de julio 1794. http://www.hndm.unam.mx/consulta/resultados/visualizar/558a33377d1ed64f16921498? resultado=8\&tipo=pa gina\&intPagina $=1 \&$ palabras $=$ Gazeta $+\mathrm{de}+\mathrm{M} \% \mathrm{C} 3 \% \mathrm{~A} 9 \mathrm{xico}_{0} \% 3 \mathrm{BVald} \% \mathrm{C} 3 \% \mathrm{~A} 9 \mathrm{~s}+\mathrm{T} \% \mathrm{C} 3 \% \mathrm{~A} 91 \mathrm{lez}$ [Consultado el 13 de julio de 2017]

45 Iguiniz, 1943: 9. 
considera que no debió de ser mucho, debido a la falta de trabajo ${ }^{46}$. Por otra noticia de la Gazeta de México del 19 de septiembre de 1807, sabemos que ya estaba nuevamente en la capital virreinal y había establecido su taller en la Calle de las Escalerillas ${ }^{47}$.

Va acompañada en el margen inferior por el título, Mater Immaculata, que se incluyó en las Letanías marianas en 1767, y hace referencia directa a su concepción inmaculada. En el centro de la composición se encuentra la Virgen, siguiendo el tipo iconográfico impuesto desde inicios del siglo XVII. Como ya hemos visto en algunas de las anteriores estampas, la figura se dispone entre el Cielo y la tierra, va vestida con una túnica blanca de finos plegados y un manto oscuro. Une sus manos en actitud orante y su hermosa cabeza está rodeada de las estrellas y de una aureola de rayos que se extienden abriendo las nubes del Cielo. Siguiendo el perfil de la Mulier amicta sole, tiene bajo sus pies la creciente con las puntas hacia arriba, al tiempo que está pisando a la serpiente con la fruta del Pecado Original en su boca como la Ipsa del Génesis, a la que hace referencia el padre Nava en el sermón ${ }^{48}$. Bajo la luna y la sierpe está el orbe.

En esta estampa se incluyen algunos de los símbolos marianos, tomados de la Tota, que se distribuyen tanto en la tierra como entre las nubes del Cielo. En la parte terrenal a cada lado de la Virgen vemos la palmera y el ciprés, mientras que sobre las bandas de nubes que rodean a la figura, se disponen el Espejo, a la izquierda, y la Torre, a la derecha. Entre las nubes también distinguimos las cabecitas aladas de unos querubines, a ambos lados.

Desde el punto de vista técnico es una obra de gran calidad, en la que este grabador demuestra su asimilación de la técnica reproductiva academicista que se funde con la espontaneidad y el dibujo característico de los grabadores independientes ${ }^{49}$.

De los últimos años del período virreinal tenemos que destacar la estampa que decora el libro, Llave de oro para abrir las puertas del Cielo: la regla y ordenaciones de las monjas de la

Inmaculada Concepción de $N^{a} S^{a}$ la Madre de Dios, editado por María Fernández de Jáuregui (Fig. 9) ${ }^{50}$. En el ángulo izquierdo del margen inferior vemos la firma del grabador, "Aguera Sc", a quien identificamos con Francisco Agüera Bustamante. Al igual que Larrea, este artista estuvo activo en los últimos años del Virreinato y trabajó independientemente de la Academia de San Carlos. Destacó su faceta de grabador de estampas devocionales como esta de la Inmaculada, y colaboró frecuentemente con las imprentas de Zúñiga y Ontiveros y la de los Jáuregui, realizando las dieciocho láminas que ilustran el famoso libro, La portentosa vida de la Muerte, de fray Joaquín Bolaños $^{51}$, que hemos de considerar una de sus aportaciones más destacadas al arte gráfico novohispano.

\footnotetext{
${ }^{46}$ Romero Terreros, 1948: 493

47 Gazeta de México, $19 \quad$ de $\quad$ septiembre $\quad$ de 1807. http://www.hndm.unam.mx/consulta/resultados/visualizar/558a335f7d1ed64f16947cad? resultado=3\&tipo=pag ina\&intPagina=5\&palabras $=$ Gazeta + de $+\mathrm{M} \% \mathrm{C} 3 \%$ A $9 x i c 0 \% 3$ BLarrea [Consultado el 13 de julio de 2017].

48 Nava, 1806: 17.

49 Donahue-Wallace, 2000: 118-119.

50 Biblioteca Miguel Lerdo de Tejada, Fondo Reservado, CM_19 255.9 C65MIS; BNM, Fondo Reservado, RSM 1815 M4CON, 60×104 mm.

51 BNM, Fondo Reservado, RSM 1792 M4BOL.
} 
Fig. 8. Atribuida a José Simón Larrea, "Mater Inmaculata", en José Ignacio María de Nava, Sermón de la Purísima Concepción predicado el 8 de diciembre de 1804, (Mariano Valdés Téllez Girón, Guadalajara, 1806). Talla dulce. Biblioteca Nacional de México, RSM 1806 G6NAV.

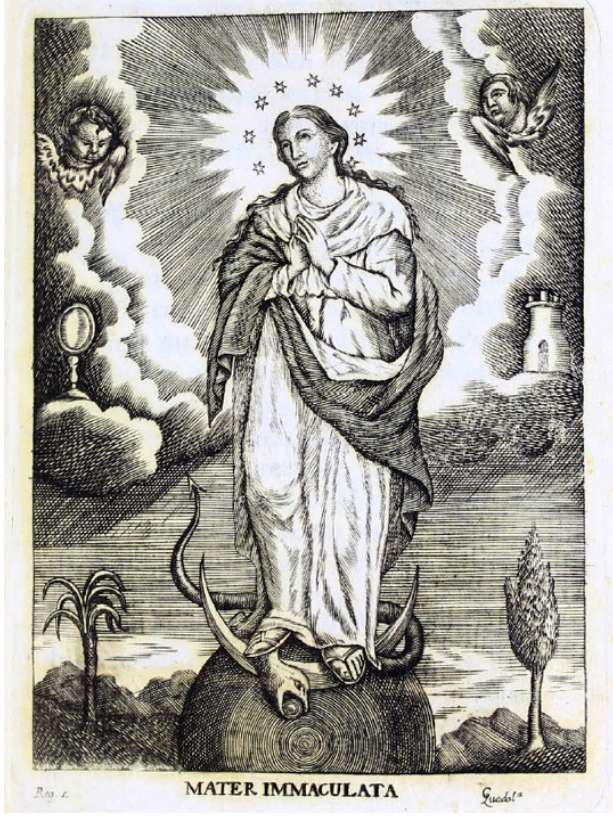

En este grabado la Inmaculada se encuentra en medio de un rompimiento de gloria, entre bandas de nubes. Como en las anteriores representaciones del tipo definitivo de la Inmaculada, apreciamos que se funden elementos tomados de la Mujer Apocalíptica, la Tota Pulchra y la Nueva Eva. A sus pies está el orbe, sobre el que se disponen la creciente con las puntas hacia arriba y la serpiente del Génesis. La figura tiene un marcado movimiento, al tener su cuerpo levemente girado hacia la izquierda, mientras que inclina la cabeza hacia el lado contrario, a ello también contribuyen los voluminosos pliegues de las telas. Esta Inmaculada tiene un marcado parecido con las de la Escuela Sevillana, sobre todo con las de Zurbarán y Murillo que tanta importancia van a tener a la hora de fijar este tipo iconográfico no sólo en España, sino en el Nuevo Mundo, en lo que tuvo un papel transcendental la estampa.

Técnicamente Agüera Bustamante demuestra un gran dominio de la talla dulce, a pesar de no formar parte del ambiente academicista dominante desde fines de la anterior centuria. En sus estampas apreciamos un rico juego de luces que logra por medio de la combinación de trazos perpendiculares y diagonales que contrastan con las zonas iluminadas para las que emplea el blanco del papel. En sus obras se percibe la influencia que ejerció el grabado neoclásico en los artistas ajenos a la Academia en Nueva España. Llama la atención que los ejemplares con los que hemos trabajado, uno fue realizado con tinta roja y el otro con tinta azul.

En la edición de 1766 hecha por la Imprenta Mexicana de este mismo libro, encontramos una magnífica estampa dibujada y abierta por Manuel Galicia de Villavicencio, como se desprende de su firma en la parte inferior de la misma (Fig.10) ${ }^{52}$. Villavicencio fue sin duda alguna uno de los impresores de estampas más importantes activos en la segunda mitad del siglo

XVIII en la capital virreinal, prueba de ello es el hecho de que colaboró con las imprentas más destacadas tanto de México como de Puebla. Su repertorio formado por más de un centenar de estampas ${ }^{53}$, incluye tanto obras religiosas como profanas, entre estas últimas podemos destacar las que ilustran las Reales Exequias en honor de la reina Isabel de Farnesio del año 1767, o las

\footnotetext{
52 BNM, Fondo Reservado, RSM 1766 M4CON, 56×74 mm.

53 Romero Terreros, 1948: 549-555.
} 
de la Historia de la Nueva España, de Francisco Antonio Lorenzana. A diferencia de algunos de sus contemporáneos, no fue un mero grabador, sino un impresor de estampas que asumió todas las facetas vinculadas al arte gráfico, desde la realización de los dibujos hasta la tirada de las mismas en su taller ${ }^{54}$.

En esta estampa se recurre a un motivo muy frecuente en el mundo novohispano, san Francisco como Seraphicus Atlas que sostiene sobre sus hombros a la Inmaculada Concepción. Este tema tiene su origen en un grabado que hizo Paulus Pontius, a partir de un boceto de Rubens, que ilustraba una tesis universitaria ${ }^{55}$. El motivo fue ampliamente reproducido en las Indias $^{56}$, tanto en el Virreinato del Perú como demuestra un lienzo conservado en la iglesia de san Agustín en Trujillo, como en Nueva España, sírvanos de ejemplo el lienzo de Basilio Salazar en la iglesia franciscana de Querétaro, del año 1637, o El misterio de la Inmaculada Concepción de Vidal Stephanus ${ }^{57}$.

En la obra de Villavicencio la composición se ha reducido a las dos figuras centrales de san Francisco y la Inmaculada. Es obvio que se trata de insistir en la defensa que hizo la orden seráfica del misterio, que desde la Edad Media se había enfrentado a los dominicos por la definición de la doctrina. La elección del motivo no es fortuita, sino que tenemos que ponerla en relación con el propio libro centrado en las normas que regían la vida de las monjas concepcionistas de los conventos novohispanos, y por otro lado, como se desprende de las Licencias del libro, el autor fue un fraile recoleto franciscano.

La composición se estructura en dos partes, la terrenal y la celestial claramente unidas entre sí, en un efecto marcadamente barroco. En el centro de la parte terrenal se encuentra san Francisco vestido con su hábito talar y el cordón con el triple nudo, con las llagas en sus manos. A diferencia de la estampa de Pontius, en la que el santo sostiene tres orbes, en ésta sobre sus hombros y brazos se apoyan las nubes del rompimiento en el que se encuentra la Inmaculada. La figura de la Virgen está en el centro de la gloria celestial, a sus pies vemos la creciente con las puntas hacia abajo, va vestida con un manto y una túnica de ricos plegados. Tras ella surge el sol con rasgos antropomórficos como ya hemos visto en otras estampas, que podríamos considerar que deriva del texto apocalíptico. Sobre su cabeza tiene una rica corona y está rodeada de resplandores, aunque no tiene las estrellas características de las representaciones de la Inmaculada. Sobre las bandas de nubes que separan el Cielo y la tierra vemos a unos angelillos en unas posturas muy inestables, el de la izquierda parece estar entregando algo al santo, quizás el cordón o un cilicio, mientras que el de la derecha sostiene una tela de abultados pliegues que cae desde la espalda de la Virgen. En los extremos de la parte terrenal se incorporan dos de los árboles de las letanías, a la izquierda el ciprés y a la derecha el olivo.

Como ya hemos indicado, Villavicencio firma la obra como dibujante y grabador. La imagen muestra sus limitaciones como dibujante, por la desproporción y la postura antinatural de las figuras, sobre todo de san Francisco. Técnicamente es una obra interesante, en la que demuestra su habilidad para emplear los buriles como apreciamos en el hábito del santo o las telas de la Virgen. Sin embargo, hay cierta tosquedad en los árboles del fondo y en los brazos de san Francisco.

El último grabado al que nos vamos a referir ilustra el libro del jesuita Francisco Javier Lazcano, Opusculum Theophilosophicum de principatu seu antelatione Marianae gratiae, que vio la luz en

54 Donahue-Wallace, 2001b: 291.

55 Stratton-Pruitt, 1988: 74. Martínez, 2004: 139. Rijksmuseum, RP-P-OB-4298, $511 \times 725 \mathrm{~mm}$. https://www.rijksmuseum.nl/en/collection/RP-P-OB-4298

${ }^{56}$ Cuadriello, 2009: 1216.

${ }^{57}$ Iglesia de Nuestra Señora de la Asunción, San Luis de Potosí. Citado por Reta, 2005: 121. 


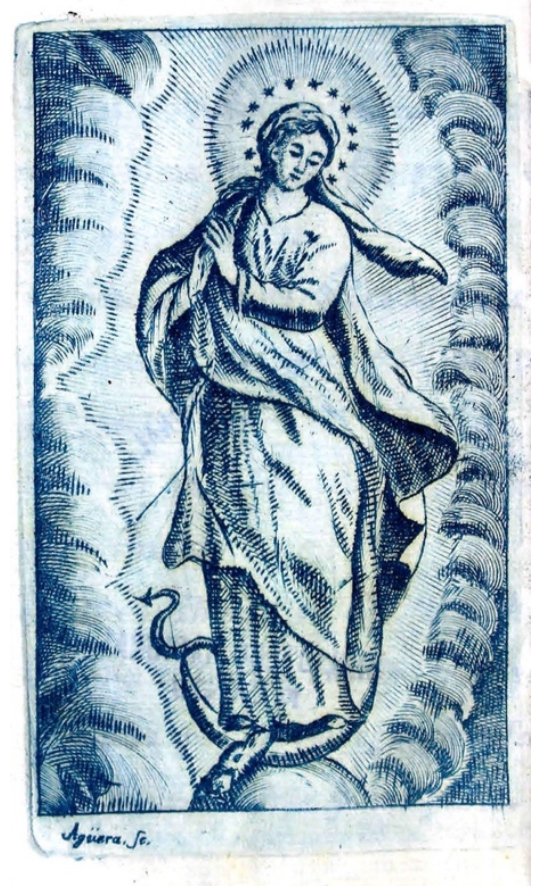

Fig. 9. Atribuida a Francisco Agüera Bustamante, "Inmaculada Concepción", en Llave de oro para abrir las puertas del Cielo: la regla y ordenaciones de las monjas de la Inmaculada Concepción de $\mathrm{N}^{a} \mathrm{~S}^{a}$ la Madre de Dios, (María Fernández de Jáuregui, México, 1815). Biblioteca Miguel Lerdo de Tejada, Fondo Reservado, CM_19 255.9 C65MIS. $(104 \times 60 \mathrm{~mm})$.

México en 1750 (Fig. 11) ${ }^{58}$. De este autor sabemos que fue un importante intelectual, catedrático de teología de la Pontificia Universidad de México, prefecto de la Congregación de la Purísima Concepción en el Colegio de san Pedro y san Pablo y ferviente defensor del culto guadalupano ${ }^{59}$, como se desprende de la dedicatoria de este libro. Desde el punto de vista iconográfico esta obra es la más interesante de las que hemos visto, puesto que se recurre a un motivo de una enorme complejidad que alude a la creación inmaculada de la Virgen en la mente de Dios antes del tiempo y a su creación terrenal libre de toda mancha. La estampa no sólo está firmada por Troncoso, sino que también está fechada en México en 1749, lo que nos genera dudas sobre la autoría, pues en estas fechas trabajaban en Ciudad México dos grabadores con ese apellido, Diego Troncoso y Baltasar Troncoso y Sotomayor. Este mismo motivo fue representado en un lienzo que Miguel Cabrera hizo para el Colegio Máximo de san Pedro y san Pablo en $1760^{60}$, lo que nos lleva a pensar que pudo ser el propio pintor quien hizo el diseño para este grabado, pues tanto Diego Troncoso como Baltasar Troncoso abrieron varias estampas basadas en sus diseños ${ }^{61}$, aunque ésta carece de la firma del inventor. Algunos han sugerido que el pintor pudo inspirase en alguna ilustración europea, para realizar el lienzo del colegio de los jesuitas, ya que en el inventario de los bienes que quedaron a su muerte, figuran varios libros con estampas ${ }^{62}$.

Este grabado tenemos que vincularlo con la estrecha relación que se estableció entre los jesuitas y el pintor oaxaqueño, de ahí que se le haya considerado "el pintor de los jesuitas" "63. Aunque como ya ha señalado Alcalá, es fundamental abordar la relación particular entre Cabrera

\footnotetext{
58 Biblioteca Miguel Lerdo de Tejada, Fondo Reservado, 200/T D49-50, 135×190 mm.

59 Zaragoza, 2015: 17.

${ }^{60}$ Cuadriello, 2001: 101.

${ }^{61}$ Donahue-Wallace, 2000: 64. Cuadriello, 2004: 94 y 121.

62 Tovar de Teresa, 1995: 62-63.

63 Tovar de Teresa, 1995: 165.
} 
Fig. 10. Manuel Galicia de Villavicencio, "San Francisco sosteniendo a la Inmaculada", en Llave de oro para abrir las puertas del Cielo: la regla y ordenaciones de las monjas de la Inmaculada Concepción de $N^{a} S^{a}$ la Madre de Dios, (Imprenta Mexicana, México, 1766). Talla dulce. Biblioteca Nacional de México, RSM 1766 M4CON. (74×56 mm).

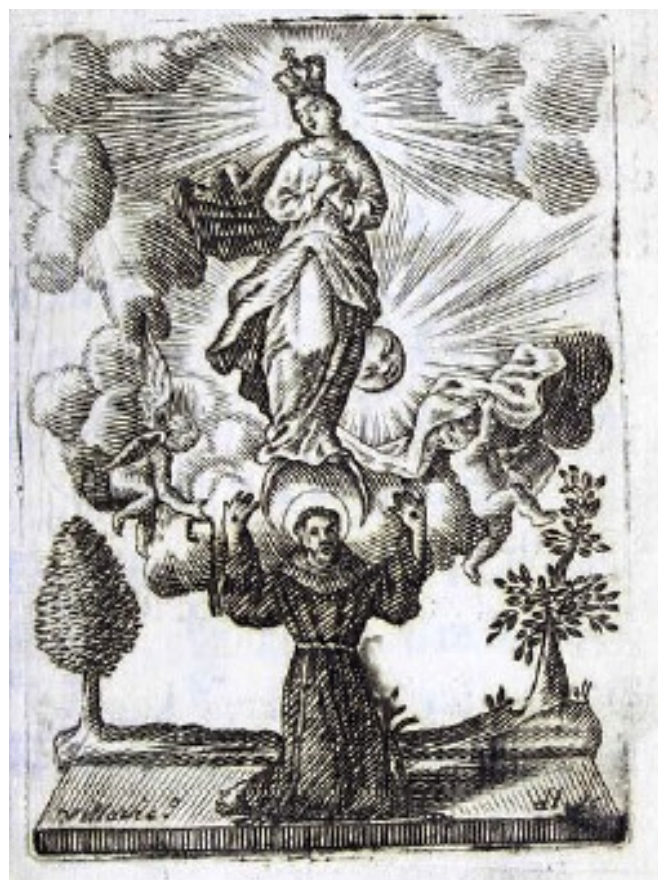

y ciertos jesuitas, para comprender el desarrollo de su obra ${ }^{64}$. En este caso particular vamos hacer hincapié en el vínculo entre el padre Francisco Javier Lazcano, autor del libro, y el pintor, prueba de ello es que Lazcano escribió uno de los dos pareceres que preceden al texto del libro del propio Cabrera, Maravilla americana, y conjunto de raras maravillas, observadas con la dirección de las Reglas de el Arte de la Pintura, editado en 1756 por la Imprenta Real y más Antiguo Colegio de san Ildefonso ${ }^{65}$, en el que elogia efusivamente al pintor ${ }^{66}$.

Por otro lado, como ya hemos indicado, el padre Lazcano fue preceptor de la Congregación de la Purísima en 1761. En el registro de ese año en el libro de la cofradía figura un "Miguel Cabrera", con el cargo de conciliario ${ }^{67}$, que se ha identificado con el pintor ${ }^{68}$. En el registro del año siguiente, Miguel Cabrera ya no aparece como oficial, aunque esto no quiere decir que no fuera miembro de la cofradía, sino que ya no ocupaba dicho cargo, pues el libro sólo recoge a los oficiales. Si ya resulta extraño que Cabrera hubiera podido acceder a la Cofradía de la Purísima, que era la más importante dedicada a la Inmaculada en la capital virreinal, lo es aún más que alcanzara el grado de oficial, en lo que tuvo un papel clave el padre Lazcano como preceptor de la misma ${ }^{69}$. No se sabe cuándo entró el pintor en la congregación, para la profesora Alcalá, debió de ser después de la década de 1750, como recompensa de todas las obras realizadas para la Compañía a lo largo de esa década y sobre todo por su apoyo al culto guadalupano ${ }^{70}$. Podemos considerar que si en el año 1761 fue nombrado oficial, lo más probable es que ya llevase un tiempo siendo miembro de la congregación. Así que es posible que entrase en ella, al

${ }^{64}$ Alcalá, 2011: 122.

65 http://cdigital.dgb.uanl.mx/la/1080026900/1080026900.PDF [consultado el 13 de julio de 2017].

66 Alcalá, 2011: 134

${ }^{67}$ Libro de la fundación de la congregación de la Limpia Concepción de Nuestra Señora, Archivo General de la Nación, Libro 229, f. 109r; citado por Alcalá, 2011: 126.

68 Alcalá, 2011: 127-131.

${ }^{69}$ Alcalá, 2011: 134.

70 Alcalá, 2011: 133. 
tiempo que hacia el lienzo para la propia capilla de la Congregación, al que nos hemos referido un poco más arriba.

La escena tiene lugar en medio de un rompimiento de gloria entre bandas de nubes. En la parte inferior hallamos a los padres de la Virgen, san Joaquín y santa Ana, de cuyos pechos germinan unos vástagos que culminan en una flor de azucena de la que brota la Inmaculada. Este motivo parece derivar de la llamada "Escena de los tallos", que como ha señalado Doménech, quizás es mejor denominarla por su fuerte sentido conceptual, La Virgen germinando del pecho de san Joaquín y santa Ana o Variante mariana del Árbol de Jesse $e^{71}$. Tendríamos que vincularlo con el de origen medieval, el Árbol de Jessé, inspirado en la profecía de Isaías y en el primer capítulo del evangelio de san Mateo, que incidía en la genealogía terrena de Cristo, uniéndola con la Casa de David. Fue posteriormente, a fines de la Edad Media cuando adquirió un sentido mariano, en lo que tuvo un importante papel el Speculum Salvatoris Mundi. Este tipo de representación surgió en el arte flamenco a fines del siglo XV e inicios del XVI, siendo uno de los primeros ejemplos una pintura de Cornelio van Coninxloo. En la Península tuvo cierto desarrollo a mediados de la centuria como apreciamos en una obra de Hernando de Esturnio de 1555 y en una vidriera de Teodoro de Holanda de la catedral de Granada de $1556^{72}$. También lo encontramos en algunas ilustraciones de libros de los siglos XVI y XVII, como en la edición alcalaína de 1572, del Flos Sanctorum, de Pedro de la Vega ${ }^{73}$, acompañando a la festividad de la Virgen de la O, y en la viñeta que ilustra la portada del libro de Francisco de León Garabito, Información en derecho por la Purissima y Limpissima Concepción de María, editado en Sevilla por Francisco de Lyra, en $1625^{74}$. En el mundo novohispano esta fórmula no se empleó a mediados del siglo XVI, pero comenzó a desarrollarse en el ecuador del XVII como demuestran las pinturas de Juan Sánchez Salmerón para la catedral de México y la conservada en el Museo del Virreinato ${ }^{75}$.

Este motivo va a tener cierto desarrollo en las artes gráficas dieciochescas, como demuestran algunas obras de los hermanos Klauber. La primera de ellas ilustra el libro de Francisco Xavier Dorn, Litaniae lauretanae ad Beata Virginis, caeliqui reginae Mariae honorem, et gloriam prima vice in domo lauretana a sanctis angelis decantattae, postea ab Ecclesia Catholica approbatae et confirmatae, symbolicis biblicis figuris in quinquaginta septem iconisimis aeneis expresae, secundum ordinem titulorum exbibitae, pia meditatione, editado en Augsburgo, en $1750^{76}$. En la que se representa a la Inmaculada de medio cuerpo brotando de una rosa, al tiempo que sujeta entre sus manos la vara de los lirios, símbolo de su pureza, en medio de un jardín, acompañada de varios versículos del Eclesiástico. El otro grabado orna el libro de Segismundo Comas y Vilar, Brevis rethoricae cursus ex Ciceronianus praecipue praeciptis, et orationibus summa diligentia collectus a reverendo Segismundo Comas et Vilar, publicado en la misma ciudad, en 1773. Éste tiene un mayor parecido con la lámina de Troncoso, pues se representa a los padres de la Virgen, de cuyos pechos brotan unos tallos que llevan a una flor de la que surge la Inmaculada ${ }^{77}$.

Volviendo a la estampa que nos ocupa, los padres de la Virgen están arrodillados a izquierda y derecha sobre unas nubes. San Joaquín apoya una de sus manos en su pecho de donde surge una de las ramas, mientras que extiende la otra y clava sus ojos en la figura de la Virgen. Santa Ana está postrada al otro lado, poniendo sus dos manos sobre su pecho de donde brota el otro vástago. En el centro de la composición está la azucena nívea de la que surge la Inmaculada. La vinculación de la Virgen con distinta flores se basa en las Letanías, como ya hemos visto, y

\footnotetext{
71 Doménech García, 2014: 65.

72 Doménech García, 2014: 66.

73 Biblioteca Histórica de la Universidad Complutense de Madrid, BH FLL 11535.

74 BNE, Salón General, Fondo Antiguo, VC/295/20.

75 Doménech García, 2014: 66-67.

76 BNM, Fondo Reservado, RFO 232.91 DOR.I.

77 De ella se conserva un ejemplar suelto en la BNE, Sala Goya, Colección Albert, Caja 5, V-58/508.
} 


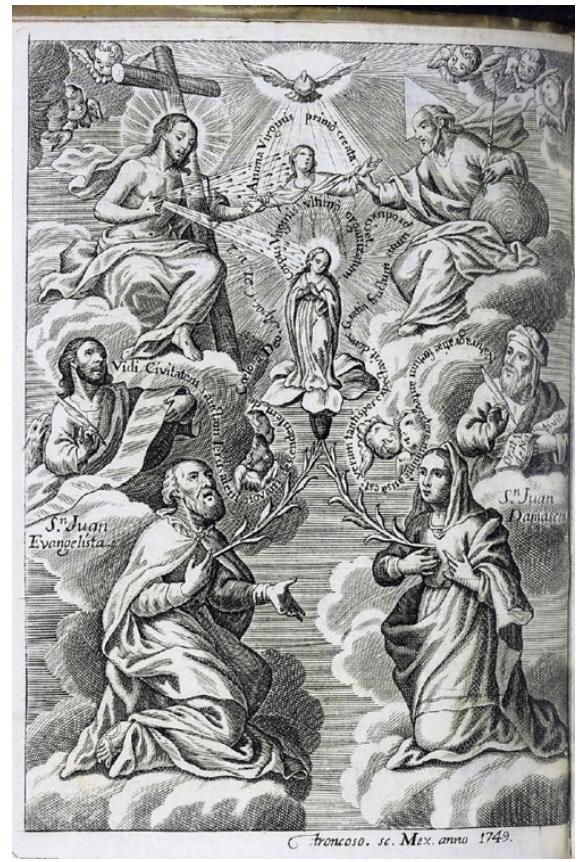

Fig. 11. Atribuida a Miguel Cabrera (inventor), Troncoso, "La creación inmaculada de la Virgen", en Francisco Javier Lazcano, Opusculum Theophilosophicum de principatu seu antelatione Marianae gratiae, (México, 1750). Talla dulce. Biblioteca Miguel Lerdo de Tejada, 200/T D49-50. (190×135 mm).

simbolizaban su pureza virginal. La idea de la Virgen brotando de una flor también se desarrolló en la literatura de la época, sírvanos de ejemplo unos versos de Antonio de Escobar y Mendoza, Nueva Jerusalén María Señora, poema heroico, que fue reeditado en México en varias ocasiones a lo largo de la centuria ${ }^{78}$. La figura de la Inmaculada responde a las tesis planteadas por Pacheco en su tratado ${ }^{79}$, pues se la capta como una niña que junta sus manitas a la altura del pecho en actitud orante e inclina suavemente su cabecita hacia su hombro izquierdo. Tiene una larga melena que le cae ondulada sobre sus hombros y alrededor de su cabeza tiene un nimbo luminoso que extiende sus rayos por toda la composición. En torno al nimbo hay una leyenda latina que dice: "Corpus Virginis ultima organizatum", que vendría a hacer hincapié en la idea de que en la concepción terrenal de la Virgen sus padres no tuvieron contacto carnal, luego estuvo libre del pecado. En el lienzo cabreriano sobre la cabeza de la figura podemos apreciar las estrellas derivadas de la Mujer Apocalíptica, que no encontramos en la lámina de Troncoso.

En la parte superior de la composición se capta la creación del alma de la Virgen en la mente divina antes del tiempo. Esta creación "Ex nihilo" no se debe sólo a Dios Padre, sino a la Trinidad al completo. Cristo y Dios Padre están sentados sobre unas nubes, a izquierda y derecha, toman de las manitas al alma de la Virgen, representada como una joven de medio cuerpo que emerge de la doncella inmaculada ${ }^{80}$. Sobre esta figura leemos otra inscripción latina que reza: "Anima Virginis primo creata" que incide en la creación del alma de la Virgen antes del tiempo. Cristo está sentado de tres cuartos hacia la derecha, dirige su mirada hacia la figura del alma de su Madre, va ataviado con un manto que deja desnudo su torso y sobre uno de sus hombros descansa la cruz. Con una de sus manos presiona la herida de la lanza de la que manan dos haces de luz con gotas de sangre que se vierten sobre las figuras del alma y el cuerpo inmaculados de la Virgen. De esta manera quizás se trata de resaltar la Encarnación del Salvador en el cuerpo y alma puros de su Madre, y el papel de ésta como corredentora. Dios Padre está

\footnotetext{
78 Doménech García, 2014: 68.

79 Pacheco, 1649: 482.

${ }^{80}$ Cuadriello, 2001: 101.
} 
sentado al lado contrario, también de tres cuartos, se sigue el tipo iconográfico del anciano con nimbo triangular, en una mano sostiene un cetro flordelisado, bajo el cual hallamos el orbe, dos de sus atributos más usuales. Sobre la figura del alma de la Virgen, rematando la composición y el eje de simetría, está la paloma del Espíritu Santo rodeada de resplandores que descienden hacia la figura de la Virgen.

Testigos y voceros de excepción de la escena son san Juan Evangelista y san Juan Damasceno, que no fueron elegidos aleatoriamente, sino que al primero se debe el Apocalipsis donde es descrita la Mulier amicta sole que se acabará identificando con la Inmaculada, mientras que Juan Damasceno, el último de los teólogos de fama universal, escribió la Oratio de Nativita Beata M. $V$, pero ha pasado a la historia de la Iglesia por su inquebrantable defensa de las imágenes frente a las tesis de los iconoclastas ${ }^{81}$. La presencia de los juanes no es extraña, pues ya les hallamos en el famoso lienzo dedicado al misterio inmaculista, de Juan de Roelas en el Museo Nacional de Escultura de Valladolid. El evangelista está a la izquierda, dirigiendo su mirada a la parte superior de la composición como si estuviera teniendo en ese instante la visión de la Mulier. Con una de sus manos sujeta una pluma con la que escribe en un largo rollo que se extiende desde su otro brazo y cae sobre las nubes. A su lado se encuentra el águila de la que únicamente atisbamos la cabeza. De la boca de san Juan sale una leyenda tomada del capítulo 21 del Apocalipsis: "Vidi Civitatem sanctam Ierusalem novam descendentem de Coelo a Deo". Este pasaje fue interpretado como imagen simbólica de la Virgen como se desprende de las palabras de sor María Jesús de Agreda:

«Por los Misterios, que Dios obró en la Ciudad Santa de Jerusalénm era mas apropósito para símbolo de la que era su Madre, y el centro, y mapa de todas las maravillas de el Omnipotente $»^{82}$.

Y un poco más adelante continua diciendo:

«Por esto la llama Ierusalen Nueva porque todos sus dones, grandeza y virtudes son nuevas, y causan nueva maravilla a los Santos. Y nueva, porque fue después de todos los Padres antiguos, Patriarcas y Profetas, y en ella se cumplieron y renovaron sus clamores, oráculos y promesas. Y nueva, porque viene sin el contagio de la culpa, y desciende de la gracia por nuevo orden suyo, y lexos de la común ley del pecado» ${ }^{83}$.

San Juan Damasceno está al otro lado, en una mano tiene una pluma con la que escribe en un libro abierto que sujeta con la otra mano, en el que leemos el título: "Oratio 1 de Nativit", de la que se toma la leyenda latina que sale de su boca: "Natura gratiae foetum anteverterem minime ausa est: verum tanti sper expectavit, donec Gratia fructum suum produxisset" que se interpreta en un sentido inmaculista.

Desde el punto de vista técnico Troncoso demuestra un dominio absolutamente excepcional de la talla dulce que le permite trasladar al cobre el complejo diseño. Emplea una amplia variedad de trazos con los que capta las luces y sombras de la composición, para las zonas iluminadas emplea el blanco del papel, mientras que en las zonas en sombra utiliza una tupida red de rombos. También se presenta como un dibujante muy talentoso, como apreciamos en las magníficas figuras de los padres de la Virgen o de la Trinidad. No hemos de pasar por alto la importancia que tenía el dibujo para los grabadores, desde los orígenes del arte gráfico, sólo hemos de ver los dibujos de algunos de los grandes artistas gráficos de la historia, como Durero o José de Ribera. El dibujo cobró una especial importancia en los estudios del grabado en la Real Academia de San Carlos, que se fundó décadas más tarde, como ha señalado Donahue-Walllace ${ }^{84}$.

\footnotetext{
81 Reta, 2005: 90.

82 María Jesús de Agreda, 1720: 128-129.

${ }^{83}$ María Jesús de Agreda, 1720: 129

84 Donahue-Wallace, 2004: 53-54.
} 
Hemos de llamar la atención sobre el hecho de que encontramos una estampa muy similar en la edición veneciana de este mismo libro del padre Lazcano, de 1755, firmada por Cayetano Zampinus como dibujante y Antonio Baratti como grabador ${ }^{85}$. Aunque presenta algunas diferencias con la de Troncoso, quizás la más llamativa es la sustitución del alma de la Virgen por una guadalupana ${ }^{86}$. No es posible pensar que esta estampa italiana se inspirase en el lienzo cabreriano del Colegio Máximo de san Pedro y san $\mathrm{Pablo}^{87}$, puesto que es cinco años anterior. Luego nos parece más probable que tomase como modelo el grabado de Troncoso. Tampoco se puede afirmar que se hiciese por iniciativa de los jesuitas novohispanos refugiados en Italia ${ }^{88}$, tras la expulsión de la Compañía de los territorios de la Monarquía Hispánica, porque ésta tuvo lugar en 1767. En cualquier caso, nos permite plantearnos la circulación de libros entre Nueva España y Europa, a través de las extensas redes tejidas por los jesuitas.

\section{A modo de conclusión.}

En este artículo hemos hecho una primera aproximación al estudio de las estampas dedicadas a la Inmaculada Concepción, abiertas a lo largo del siglo XVIII y en las primeras décadas del XIX en Nueva España. Atendiendo principalmente a criterios iconográficos, quedando demostrado la pervivencia de tipos poco usuales en la Península para estas fechas como el de la Tota Pulchra, que conviven con el tipo definitivo que hemos podido ver en otras estampas. Además hemos hallado algunas obras de temática inmaculista con un fuerte contenido conceptual. Al tratarse todas ellas de estampas que ilustran libros, tenemos que considerar que no estaban dirigidas al público en general, sino a aquella población que podía acceder a los libros, que a pesar que en esta centuria era más amplia que en las anteriores, no era ni mucho menos mayoritario. Sobre todo, tenemos que tener en cuenta que varias de estos grabados estaban destinados a ornar las reglas y constituciones de los conventos concepcionistas de la capital virreinal, destinados al uso de las monjas de dichos cenobios.

También hemos tratado de incidir en los aspectos técnicos, de lo que deducimos que la tesis planteada por algunos, que con la aparición de la talla dulce en la primera mitad del siglo XVII, cayó en desuso la entalladura, no se puede considerar cierta. Por último, hemos podido comprobar como todas las estampas abiertas por medio de la talla dulce tienen las firmas de los grabadores, quizás como una forma de poner de relieve su trabajo, ya que no se consideraban meros artesanos, sino artistas, y algunos de ellos como es el caso de Villavicencio eran auténticos empresarios $^{89}$.

\footnotetext{
85 BNM, Fondo Reservado, RFO 232.9312 LAZ.o.; Biblioteca Histórica UCM, BH DER 12339.

86 De la Maza, 1984: pp. 81-82; Cuadriello, 2001: p. 103.

87 De la Maza, 1984:pp. 81-82; Cuadriello, 2001: p. 103.

${ }^{88}$ Cuadriello, 2001: p. 103.

${ }^{89}$ Donahue-Wallace, 2001b: 291.
} 


\section{Bilbiografía.}

María Jesús de Agreda, Mystica Ciudad de Dios, milagro de su omnipotencia y abismo de la gracia: Historia Divina y vida de la Virgen Madre de Dios, Reyna, y Señora Nuestra, María Santissima, restauradora de la culpa de Eva, y medianera de la gracia, Madrid, Imprenta de la causa de la Venerable Madre, (1720).

Alcalá, L.E.: "Miguel cabrera y la congregación de la Purísima", en Anales del Instituto de Investigaciones Estéticas, Vol. XXXIII, no 99, (2011), pp. 111-136.

Cabello Morales, P. V.:“La Inmaculada Concepción”, en Gratia Plena: La llena de Gracia, Córdoba, Publicaciones de la obra social y cultural Cajasur, (2004).

"El Obrador Trinitario o María Guadalupe creada en idea, imagen y materia", en Catálogo de la exposición, El Divino pintor: la creación de María de Guadalupe en el taller celestial, Ciudad de México, Museo de la Basílica de Guadalupe, (2001), pp. 61-205.

Cuadriello, J.:, "Virgo Potens. La Inmaculada Concepción o los imaginarios del Mundo Hispánico", en Pintura de los Reinos. Identidades Compartidas. Territorios del mundo hispánico, siglos XVI-XVIII, México, Fondo Cultural Banamex, (2009), pp. 1169-1264.

Díez, J.: Aljaba apostólica de penetrantes flechas, para rendir la fortaleza del duro Pecador, en varias Canciones y Saetas, que acostumbran a cantar en sus Misiones los RR.PP. Misioneros Apostólicos de N.S.P. San Francisco, México, Imprenta de la Viuda de Miguel Ribera, (1731).

"La Concepción de María en el tiempo. Recuperación de fórmulas tempranas de representación de la Inmaculada Concepción en la retórica visual del virreinato de Nueva España”, Revista de Dialectología y Tradiciones Populares, Vol. LXIX, nº 1, (2014), pp. 53-76.

Doménech García, S.: "La recepción de la tradición hispánica de la Inmaculada Concepción en Nueva España: el tipo iconográfico de la Tota Pulchra”, Espacio, Tiempo y Forma, Serie VII, (2015), pp. 275-309.

Prints and printmakers in Viceregal Mexico City, 1600-1800, Albuquerque, New Mexico, The University of New Mexico, (2000).

Donahue-Wallace, K.: "Printmakers in Eighteenth-Century Mexico City: Francisco Sylverio, José Mariano Navarro, José Benito Ortuño and Manuel Galicia de Villavicencio", Anales del Instituto de Investigaciones Estéticas, UNAM, $\mathrm{n}^{\circ}$ 78, (2001), pp. 221-234.

Donahue-Wallace, K.: "Nuevas aportaciones sobre los grabadores novohispanos", en las Actas III Congreso Internacional del Barroco Americano: Territorio, Arte, Espacio y Sociedad, (2001), pp. 290297.

Donahue-Wallace, K.: "El grabado en la Real Academia de San Carlos de Nueva España, 17831810", Tiempos de América: revista de bistoria, cultura y territorio, no 11, (2004), pp.49-61.

Fernández Gracia, R.: La Inmaculada Concepción en Navarra. Arte y devoción durante los siglos del Barroco. Mentores, artistas e iconografía, Pamplona, Eunsa, (2004).

"Perfiles icnográficos de la Mujer del Apocalípsis como símbolo mariano (I). Ab initio et ante saecula creata sum", Ars Longa, n 6, (1995), pp. 187-197.

García Mahíques, R.: "Perfiles icnográficos de la Mujer del Apocalípsis como símbolo mariano (II). Ab initio et ante saecula creata sum", Ars Longa, no 7-8, (1996-1997), pp. 177-184.

Iguiniz, J. B.: Las artes gráficas en Guadalajara, Ciudad de México, Talleres Linotipográficos Numancia, (1943).

Martínez, I.: "Estandarte de la monarquía española. El uso político de la Inmaculada Concepción", en La Concepción de María Inmaculada. La celebración del dogma en México, (2004), pp. 123-154. 
Pacheco, F.: Arte de la pintura, Sevilla, Imprenta de Simón Fajardo, (1649).

Reta, M.: "El ingenio humano en favor de María Inmaculada: la defensa teológica del Misterio", en el catálogo de la exposición, Un privilegio sagrado. La Concepción de María Inmaculada, Ciudad de México, Museo de la Basílica de Guadalupe, (2005), pp. 75-122.

Rivera, L.: "La idea y la materia. La concepción de María siempre Inmaculada", en Un privilegio Sagrado: La Concepción de María Inmaculada, Museo de la Basílica de Guadalupe, (2006), pp. 2974.

Romero de Terreros, M.: Grabados y grabadores en la Nueva España, Ciudad de México, Ediciones de Arte Mexicano, (1948).

Sebastián, S.: Contrarreforma y barroco, Madrid, Alianza-Forma, (1981).

Stratton-Pruitt, S.: La Inmaculada Concepción en el arte español, Madrid, Fundación Universitaria Española, (1988).

Tovar de Teresa, G.: Miguel Cabrera: pintor de cámara de la reina celestial, México, Espejo de obsidiana, (1995).

Tormo, E.: La Inmaculada y el arte español, Madrid, Fototipia de Hauser y Menet, (1915).

Trens, M.: María: iconografía de la Virgen en el arte español, Madrid, Plus Ultra, (1946).

Vargaslugo, E.: "Imágenes de la Inmaculada Concepción en la Nueva España", Anuario de Historia de la Iglesia, (2004), pp. 67-78.

VV.AA., Historia de la Iglesia en España, Madrid, Biblioteca de Autores Cristianos, (1979), Vol. IV.

Zaragoza, V.: "Miguel Cabrera y la Compañía de Jesús", en el catálogo de la exposición, Miguel Cabrera: las tramas de la creación, Museo Nacional del Virreinato, Tepotzotlan, (2015), pp. 15-24 